\title{
Effects of Biotin Deficiency on Growth, Morphology and Sporulation in Bacillus megaterium NCIB7581
}

\author{
By R. M. AL-SSUM AND P. J. WHITE \\ Department of Microbiology, The University, Western Bank, Sheffield Sז0 2TN
}

(Received 8 October 1976)

\section{SUMMARY}

Bacillus megaterium strain NCIB758I grew at $30^{\circ} \mathrm{C}$ in a simple chemically defined medium without biotin. At $37^{\circ} \mathrm{C}$ the bacteria grew more slowly in the same medium and were deformed, especially during the earlier stages of growth, as filaments or with swollen ends. Addition of biotin restored the normal appearance and rate of growth at $37^{\circ} \mathrm{C}$. The organisms synthesized more biotin at $30^{\circ} \mathrm{C}$ (I I ng $1^{-1}$ in a stationary phase culture) than at $37^{\circ} \mathrm{C}\left(\mathrm{I} \cdot 4 \mathrm{ng} \mathrm{l}^{-1}\right)$.

Addition of either aspartate, malate, fumarate or acetate to minimal medium also restored normal morphology and accelerated the growth rate in biotindeficient medium at $37^{\circ} \mathrm{C}$. Neither acetate nor aspartate increased synthesis of biotin at $37^{\circ} \mathrm{C}$.

After growth in medium containing only $0.2 \%$ glucose almost every organism in the culture was able to sporulate at $30^{\circ} \mathrm{C}$ whether or not biotin was added. About $5^{\circ}$ times fewer spores were formed at $37^{\circ} \mathrm{C}$ without biotin; the yield of spores increased about 20 -fold at this temperature when biotin, aspartate or dipicolinate was added.

\section{INTRODUCTION}

White (1972) studied the nutritional requirements of I I strains of Bacillus megaterium. Strain NCIB758I required biotin to grow from small inocula at $37^{\circ} \mathrm{C}$ in a chemically defined medium with glucose (or glycerol) and ammonium sulphate as the principal nutrients. However, the organisms could be propagated from large inocula at $37^{\circ} \mathrm{C}$ without biotin. The effect of biotin deficiency $\left(\right.$ at $37^{\circ} \mathrm{C}$ ) ranged from production of some abnormally shaped organisms on solid medium to inability of a small inoculum to grow in liquid medium. In this study the role of inoculum size was examined further; conditions for the production of cultures containing only abnormally shaped organisms were devised; the synthesis of biotin was measured at both $37^{\circ} \mathrm{C}$ and $30^{\circ} \mathrm{C}$; the abilities of the organisms to sporulate at $37^{\circ} \mathrm{C}$ and $30^{\circ} \mathrm{C}$ were compared with or without biotin; and the deformities caused by biotin deficiency at $37^{\circ} \mathrm{C}$ were examined by electron microscopy.

A preliminary report of some of these results has already been published (Al-ssum \& White, 1974).

\section{METHODS}

Organisms. Bacillus megaterium NCIB7581 was maintained at $37^{\circ} \mathrm{C}$ on nutrient agar slopes that were incubated at $37^{\circ} \mathrm{C}$ overnight, then stored at $2{ }^{\circ} \mathrm{C}$ and subcultured monthly. For day-to-day use, inocula were prepared from organisms grown overnight at $37^{\circ} \mathrm{C}$ on slopes of medium AI. Lactobacillus arabinosus NCIB9085 was grown overnight in stabs of yeast extract ( $(\mathrm{\%} \%, \mathrm{w} / \mathrm{v})$, Difco tryptone (I \%, w/v), glucose $(0 . \mathrm{I} \%, \mathrm{w} / \mathrm{v}), \mathrm{KH}_{2} \mathrm{PO}_{4}(0.2 \%, \mathrm{w} / \mathrm{v})$ 
$\mathrm{CaCO}_{3}(0.3 \%, \mathrm{w} / \mathrm{v})$, and agar $(\mathrm{I} \cdot 5 \%, \mathrm{w} / \mathrm{v})$, at $30{ }^{\circ} \mathrm{C}$ and subcultured monthly. For day-today use, inocula were prepared from organisms grown overnight in yeast extract $(\mathrm{I} \%, \mathrm{w} / \mathrm{v})$ plus glucose $(\mathrm{I} \%, \mathrm{w} / \mathrm{v})$ at $30^{\circ} \mathrm{C}$.

Media. The chemically defined medium AI was that of White (1972) with glycerol (usually $\mathrm{I} \%, \mathrm{w} / \mathrm{v}$ ) as carbon source. Medium A2 contained glucose (usually $\mathrm{I} \%, \mathrm{w} / \mathrm{v}$ ) instead of glycerol. Biotin assay medium (Difco no. 0419-15) was rehydrated by dissolving $7.5 \mathrm{~g}$ in $100 \mathrm{ml}$ distilled water, with boiling.

Biotin extraction and assay. (i) Extraction [modified from Pai \& Lichstein (1962)]. Each stationary phase culture was autoclaved at $\mathrm{I}_{2 \mathrm{I}}{ }^{\circ} \mathrm{C}$ for $20 \mathrm{~min}$, centrifuged at $5000 \mathrm{~g}$ for $20 \mathrm{~min}$ and the supernatant liquid was kept. The killed organisms were washed twice with warm distilled water $\left(50\right.$ to $60^{\circ} \mathrm{C}$ ) by centrifuging at $5000 \mathrm{~g}$. All supernatant liquids were combined and dried at $50{ }^{\circ} \mathrm{C}$ in a rotary evaporator. The dried residue was extracted with $10 \mathrm{ml}$ ethanol ( $100 \%)$ three times, and the solid was discarded. Ethanol was evaporated and the residue was extracted with warm water $\left(80^{\circ} \mathrm{C}\right)$ five times. The water extracts were combined and concentrated to a small volume.

Presence of the vitamin in the extractable material was proved by its growth-promoting activity for L. arabinosus; this activity was lost after pre-incubation (of $0.1 \mathrm{ml}$ extract containing I to $2 \mathrm{ng}$ biotin) for $15 \mathrm{~min}$ with avidin $(5 \mu \mathrm{g})$ at $30^{\circ} \mathrm{C}$.

(ii) Assay. Test tubes were prepared containing $5 \mathrm{ml}$ rehydrated biotin assay medium, increasing amounts of biotin (in the range o to $\mathrm{I} \mathrm{ng}$ ) or test material, plus water to give a total volume of $10 \mathrm{ml}$ per tube. The tubes were autoclaved at $\mathrm{I} 2 \mathrm{I}{ }^{\circ} \mathrm{C}$ for $15 \mathrm{~min}$. Lactobacillus arabinosus was grown overnight in yeast extract plus glucose $(5 \mathrm{ml})$, washed in $0.05 \mathrm{M}-\mathrm{Tris} / \mathrm{HCl}$ buffer, $\mathrm{pH} 7$, then in distilled water, and suspended in $100 \mathrm{ml} 0.9 \%(\mathrm{w} / \mathrm{v})$ $\mathrm{NaCl}$. One drop of this suspension was used as the inoculum for each tube, and the tubes were incubated (upright, stationary) at $30^{\circ} \mathrm{C}$ for $72 \mathrm{~h}$. Extinctions were measured at $650 \mathrm{~nm}$ and the amount of biotin in test samples was calculated from the standard curve.

Growth of B. megaterium on solid and in liquid medium. Different sizes of inocula, washed first in $0.05 \mathrm{M}$-Tris/ $\mathrm{HCl}$ buffer, $\mathrm{pH} \mathrm{7.4}$, then in $0.9 \% \mathrm{NaCl}$ and finally in distilled water, were seeded on to the surface of $8 \mathrm{~cm}$ diam. plates of medium AI (about $20 \mathrm{ml}$ ) with biotin ( $10 \mu \mathrm{g} \mathrm{l}^{-1}$ ) or without biotin and incubated at 30 or $37^{\circ} \mathrm{C}$ for 12 to $16 \mathrm{~h}$. Liquid cultures were usually grown in $50 \mathrm{ml}$ medium AI with biotin $\left(10 \mu \mathrm{g} \mathrm{l}^{-1}\right)$ or without biotin in $250 \mathrm{ml}$ conical flasks. These were incubated with shaking (about 200 gyrations $\min ^{-1}$ ) at 30 or $37^{\circ} \mathrm{C}$. Turbidities of liquid cultures were measured with an EEL colorimeter as described by White (1972).

Sporulation. Spores of $B$. megaterium NCIB758 I were obtained by growing the organisms at 37 or $30{ }^{\circ} \mathrm{C}$ in liquid medium $\mathrm{A2}$ containing glucose $(0.2 \%)$ and $\mathrm{I} \mathrm{mM}-\mathrm{CaCl}_{2}$ (added to the medium after autoclaving), with or without supplements, for 35 to $48 \mathrm{~h}$. The number of heat-resistant spores was assessed by incubating the suspension at $60^{\circ} \mathrm{C}$ for $30 \mathrm{~min}$, and then plating diluted samples on nutrient agar that was incubated at $30^{\circ} \mathrm{C}$ for $24 \mathrm{~h}$. Colonies were counted and the number of spores per $\mathrm{ml}$ culture was calculated.

Electron microscopy. The organisms were grown on plates of medium AI with or without biotin at $37^{\circ} \mathrm{C}$ for 10 to $16 \mathrm{~h}$. They were then scraped off the plates, washed and fixed with $3 \%(\mathrm{v} / \mathrm{v})$ glutaraldehyde in $0 \cdot 1 \mathrm{M}$-phosphate buffer $\mathrm{pH} 7 \cdot 2$ overnight. After washing in the same buffer containing sucrose $(6.84 \%, \mathrm{w} / \mathrm{v})$, the organisms were treated for $90 \mathrm{~min}$ in $2 \%$ $(\mathrm{w} / \mathrm{v}) \mathrm{OsO}_{4}$ in $0.1 \mathrm{M}$-phosphate buffer $\mathrm{pH} \mathrm{7.2}$. Dehydration was by treatments (each $30 \mathrm{~min}$ ) with increasing concentrations of ethanol ranging between $20 \%(\mathrm{v} / \mathrm{v})$ and $100 \%$. The organisms were embedded in dry ethanol/epon (I:I, v/v) for $30 \mathrm{~min}$; then ethanol/epon $(\mathrm{I}: 3, \mathrm{v} / \mathrm{v})$ for $30 \mathrm{~min}$ and full strength epon overnight. The samples were blocked out in 


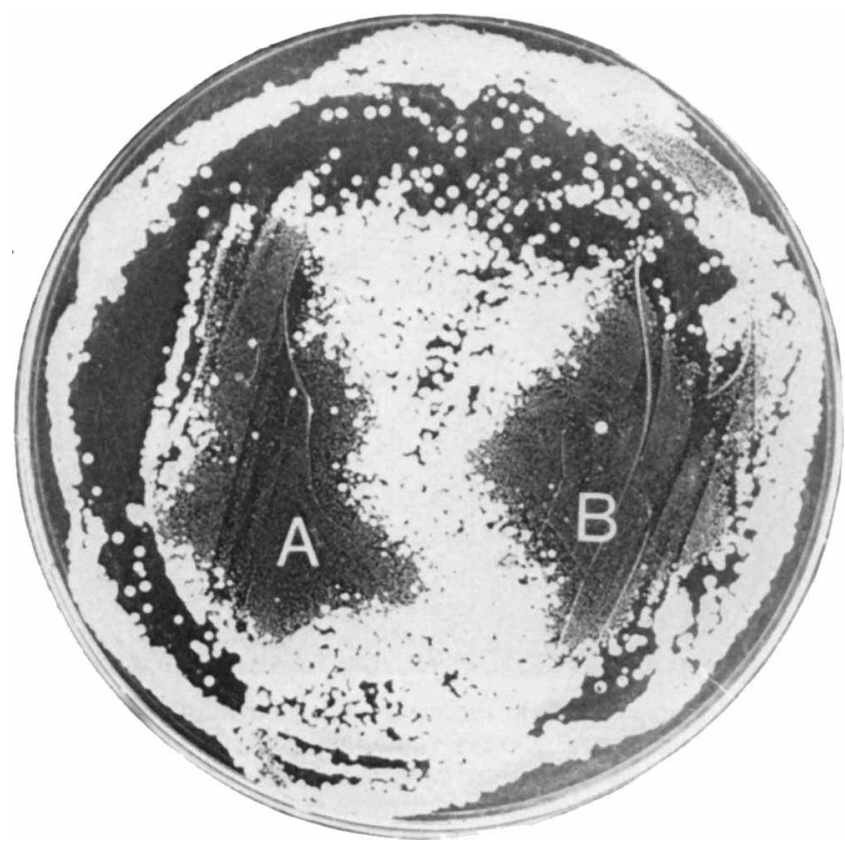

Fig. I. Surface growth of B. megaterium NCIB7581 on medium A2 without biotin at $37^{\circ} \mathrm{C}$. About $2 \times 10^{6}$ organisms (from a nutrient agar slope; in $0.1 \mathrm{ml}$ water) were spread over the surface of $30 \mathrm{ml}$ solid medium in a Petri dish $\left(8 \mathrm{~cm}\right.$ diam.). The plate was incubated overnight at $37^{\circ} \mathrm{C}$. On longer incubation, growth in the zones of minute colonies (A and B) gradually became heavier until these zones were almost indistinguishable.

gelatine capsules using fresh epon resin and polymerized at $30^{\circ} \mathrm{C}$ for $8 \mathrm{~h}$. Sections, cut on a Reichert $\mathrm{OmU}_{3}$ ultramicrotone using a Dupont diamond knife, were collected on 200-mesh grids prepared with formvar support films and then stained with uranyl acetate followed by lead citrate (Echlin, 1964).

\section{RESULTS}

Bacillus megaterium NCIB758I produced two types of growth on an agar surface $(8 \mathrm{~mm}$ diam.) of medium Ar or A2 (30 ml without biotin) at $37^{\circ} \mathrm{C}$ from an inoculum of about $10^{6}$ organisms. These two types of growth occupied zones that were distinguished by their appearance: a zone (or zones) of heavy confluent growth and other zones of minute colonies (Fig. I). An inoculum of $5 \times 10^{6}$ organisms per plate produced heavy and confluent growth with no sign of the zones of small colonies. On the other hand, smaller inocula of about $10^{2}$ to $10^{3}$ organisms required long incubation times (about $48 \mathrm{~h}$ ) to grow at $37^{\circ} \mathrm{C}$ to colonies of about $1 \mathrm{~mm}$ diam., and no smaller colonies were seen.

Organisms from the zones of heavy growth appeared normal under the phase contrast microscope, i.e. rod shaped and occurring singly or in short chains (Fig. 2a). Organisms from the small colonies were filamentous, twisted and often swollen at their ends (Fig. $2 b$ ).

In liquid medium $\mathrm{Ar}$ at $37{ }^{\circ} \mathrm{C}$ an inoculum of $2 \times 10^{6}$ organisms per $50 \mathrm{ml}$ produced two types of organisms: normally shaped rods that were similar to those seen from the heavy growth zones on solid medium, and long filaments that were twisted and swollen. An inoculum of $5 \times 10^{6}$ organisms produced only normally shaped rods. Decreased numbers of bacteria ( $10^{2}$ or $10^{3}$ organisms) gave no growth in liquid medium AI at $37^{\circ} \mathrm{C}$. 

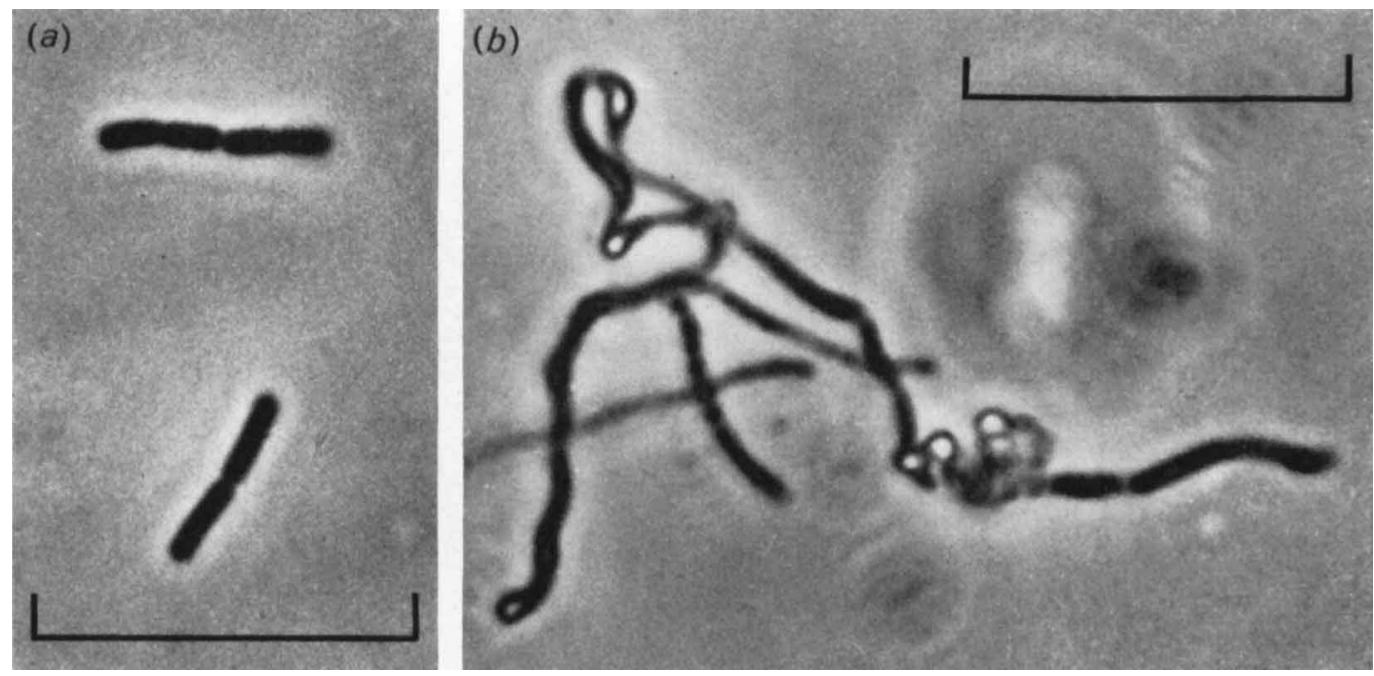

Fig. 2. Bacillus megaterium NCIB7581 from surface growth on medium A2 without biotin at $37^{\circ} \mathrm{C}$. Unstained organisms were suspended in water containing $10 \%(\mathrm{w} / \mathrm{v})$ gelatine and photographed under phase contrast. (a) Normal organisms from a zone of confluent growth; $(b)$ filamentous organisms from a zone of minute colonies. Bar markers represent $20 \mu \mathrm{m}$.

\section{Biotin requirement}

Abnormal morphology in the absence of biotin has not been observed below $33^{\circ} \mathrm{C}$, either in liquid or on solid medium AI. Above this temperature, deformity of the growing organisms, and a requirement for biotin to prevent this and to allow normal growth, (White, 1972) became noticeable if less than $\mathrm{I} \times 10^{6}$ organisms were used as the inoculum for $50 \mathrm{ml}$ liquid medium. At $37^{\circ} \mathrm{C}$ the phenomenon became more obvious and reproducible. However, the organisms could still grow at higher temperatures, e.g. $40^{\circ} \mathrm{C}$, without biotin, but a larger inoculum was required $\left(4 \times 10^{7}\right.$ organisms in $\left.50 \mathrm{ml}\right)$ and the growing organisms were always deformed.

The presence of two morphological types (normal and filamentous) in the same culture at $37^{\circ} \mathrm{C}$ without biotin made it difficult to obtain the filamentous forms without the normal ones. On transfer to fresh medium without biotin, normal or deformed organisms continued to give a mixed population after incubation at $37^{\circ} \mathrm{C}$. Hence, conditions favourable for production of only the filamentous forms at $37^{\circ} \mathrm{C}$ were sought. The inoculum was washed in sterile $0.05 \mathrm{M}$-Tris/ $\mathrm{HCl}$ buffer, $\mathrm{pH} \mathrm{7.4}$, then in $0.9 \% \mathrm{NaCl}$ and finally in distilled water. The washed inoculum ( $10^{6}$ organisms) was plated on medium $\mathrm{AI}_{\mathrm{I}}$ and incubated at $37^{\circ} \mathrm{C}$ for Io to $12 \mathrm{~h}$. The organisms formed only minute colonies of filamentous forms. Occasionally there were a few colonies of normally shaped organisms, though never more than 10 colonies on one plate. Only when liquid medium AI was brought to $37^{\circ} \mathrm{C}$ before inoculation did washed organisms give cultures consisting solely of filamentous forms. However, in liquid cultures all the deformities in the absence of biotin at $37^{\circ} \mathrm{C}$ were transient, and normally shaped organisms became predominant on longer incubation ( $24 \mathrm{~h}$ ). Presumably, variants that can synthesize biotin at $37^{\circ} \mathrm{C}$ arise frequently, and the biotin produced by these organisms then allows normal growth of the remaining bacteria that have limited ability to make the vitamin.

Swollen and twisted organisms similar to those formed in the absence of biotin were also produced when $B$. megaterium NCIB758I was grown at $37^{\circ} \mathrm{C}$ under certain conditions in 
Table I. Effects of various additions to medium AI on growth of

B. megaterium NCIB7581 at $37^{\circ} \mathrm{C}$

All the additions (except biotin) were sterilized separately and added to the molten medium at $45^{\circ} \mathrm{C}$ to give the required concentration. Plates were spread with $0.1 \mathrm{ml}$ bacterial suspension (about $2 \times 10^{6}$ organisms) and incubated at $37^{\circ} \mathrm{C}$ for 12 to $24 \mathrm{~h}$.

\begin{tabular}{|c|c|c|}
\hline Addition & $\begin{array}{l}\text { Concentration } \\
\left(\mathrm{mg} \mathrm{l}^{-1}\right)\end{array}$ & $\begin{array}{l}\text { Growth after } \\
12 \text { to } 24 \mathrm{~h}\end{array}$ \\
\hline Biotin & 0.001 & $\begin{array}{l}+++ \\
+++\end{array}$ \\
\hline L-Aspartate & 100 & $+t+$ \\
\hline L-Glutamate & 100 & $++\mathbf{M}$ \\
\hline D-Aspartate & 100 & - \\
\hline D-Glutamate & 100 & - \\
\hline L-Malate & 100 & +++ \\
\hline Na fumarate & 100 & +++ \\
\hline Na oleate & 50 & - \\
\hline Na malonate & 50 & $++\mathbf{M}$ \\
\hline $\mathrm{Na}$ oxoglutarate & 100 & $++\mathbf{M}$ \\
\hline Na palmitate & 50 & - \\
\hline $\mathrm{Na}$ succinate & 100 & $+\mathrm{MM}$ \\
\hline $\mathrm{Na}_{3}$ citrate $\left(2 \mathrm{H}_{2} \mathrm{O}\right)$ & 100 & $+\mathbf{M M}$ \\
\hline Pimelic acid & IO & $+\mathbf{M M}$ \\
\hline $\mathrm{Na}$ acetate $\left({ }_{3} \mathrm{H}_{2} \mathrm{O}\right)$ & 500 & +++ \\
\hline $\mathrm{Na}$ bicarbonate & 50 & - \\
\hline None & & $+\mathrm{MM}$ \\
\hline
\end{tabular}

+++ , Heavy confluent growth within $12 \mathrm{~h}$ incubation; $++\mathrm{M}$, heavy confluent growth within $12 \mathrm{~h}$ incubation but also a small zone (or zones) of minute colonies; + MM, zone or zones of minute colonies occupying most of the agar surface; -, no growth after $24 \mathrm{~h}$ incubation at $37^{\circ} \mathrm{C}$.

medium AI containing biotin. For example, growth in the presence of I mM-dipicolinic acid gave very twisted organisms, as did growth with methicillin (about $0.2 \mu \mathrm{g} \mathrm{ml}^{-1}$ ) or the detergent Triton X-I $00\left(5 \mu \mathrm{g} \mathrm{ml}^{-1}\right)$, and in stationary phase cultures on solid medium AI many organisms became swollen at their ends, presumably as a consequence of autolysis without sporulation.

\section{Replacement of biotin}

Medium AI was supplemented with several compounds structurally unrelated to biotin (Table I). Compounds that allowed normal growth at $37^{\circ} \mathrm{C}$ without biotin were L-aspartate, L-malate, fumarate, glutamate and acetate. Pimelic acid, which is a precursor of part of the biotin molecule (see review by Eisenberg, 1973) as a CoA derivative, was ineffective. The rates of growth of the organisms at $37^{\circ} \mathrm{C}$ in liquid medium AI with various additions were compared with the rate in unsupplemented medium Ar. L-Aspartate (100 $\mathrm{mg} \mathrm{l}^{-1}$ ) or L-malate (I00 $\mathrm{mg} \mathrm{1}^{-1}$ ) allowed growth that was about as rapid and heavy as with biotin ( $10 \mu \mathrm{g}^{-1}$ ). When the glycerol in medium AI was entirely replaced by equimolar sodium acetate, growth in liquid culture was poor. The medium became alkaline (above pH 9), as would be expected from the complete oxidation of sodium acetate to water, $\mathrm{CO}_{2}$ and $\mathrm{NaOH}$. Better growth with sodium acetate (trihydrate; $0.5 \mathrm{~g} \mathrm{l}^{-1}$ ) occurred when some glycerol $(0.25 \%)$ was also present. With higher concentrations of glycerol ( $1 \%)$, addition of acetate still restored the normal morphology (and rate of growth) in the absence of biotin.

\section{Biotin content of stationary phase cultures grown at $30^{\circ} \mathrm{C}$ or $37^{\circ} \mathrm{C}$}

Growth of the organisms at $30^{\circ} \mathrm{C}$ in medium AI was normal (only short rods) regardless of the inoculum size, and there was no requirement for biotin. These observations suggested 
Table 2. Sporulation of biotin-sufficient and biotin-deficient organisms

Bacillus megaterium was grown in medium A2 (containingonly $0.2 \%$ glucose, instead of $1 \%$ ) with I $\mathrm{mm}-\mathrm{CaCl}_{2}$, and supplemented as indicated. All cultures grew (before sporulation) to about the same turbidity (colorimeter reading $\mathrm{I} \cdot 8$ to $2 \cdot 0$ ) within $20 \mathrm{~h}$. After $36 \mathrm{~h}$ samples were taken to determine the number-of heat-resistant spores that survived heating at $60^{\circ} \mathrm{C}$ for $30 \mathrm{~min}$ and were able to grow at $30^{\circ} \mathrm{C}$ when plated on nutrient agar. This count did not increase on longer incubation. Results show the mean number of spores \pm the standard deviation, with the number of measurements shown in parentheses.

Medium

A2

$\mathrm{A} 2+$ biotin $\left(1 \mu \mathrm{g} \mathrm{l}^{-1}\right)$

$\mathrm{A} 2+\mathrm{L}$-aspartate $\left(\mathrm{I} 00 \mathrm{mg} \mathrm{ml}^{-1}\right)$

A2 + dipicolinic acid (1 $\mathrm{mm}$ )

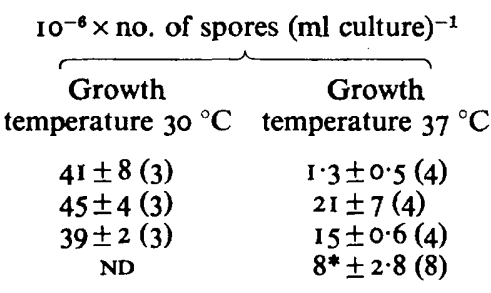

ND, Not done.

* Spores from this culture showed an increased lag period ( 2 days instead of $I$ day) before forming visible colonies on nutrient agar.

either that more biotin was needed at $37^{\circ} \mathrm{C}$ than could be met by endogenous synthesis, or that biotin synthesis at $37^{\circ} \mathrm{C}$ fell below the level needed for normal growth. Hence, the biotin contents of stationary phase cultures were measured after growth at 30 or $37^{\circ} \mathrm{C}$.

The culture grown in medium $\mathrm{AI}$ at $37^{\circ} \mathrm{C}$ contained only about $\mathrm{O} \cdot \mathrm{I}$ as much biotin $\left(\mathrm{I} \cdot 4 \mathrm{ng} \mathrm{l}^{-1}\right)$ as did that grown at $30^{\circ} \mathrm{C}\left(\mathrm{II} \mathrm{ng} \mathrm{l}^{-1}\right)$. This measured biotin represents the biotin content of the medium, plus biotin that could be released from the organisms by autoclaving. Covalently-bound biotin was released by acid hydrolysis of the killed organisms and was $0.0 \mathrm{ng}^{-1}$ from organisms grown at $30^{\circ} \mathrm{C}$, and much less from organisms grown at $37^{\circ} \mathrm{C}$ (only traces).

Surprisingly, compounds that allowed normal growth in the absence of biotin at $37^{\circ} \mathrm{C}$ decreased biotin synthesis. In medium AI plus $\mathrm{L}$-aspartate ( $\left.100 \mathrm{mg} \mathrm{l}^{-1}\right)$, biotin synthesis was $\mathrm{I} .5 \mathrm{ng}^{-1}$ at $30^{\circ} \mathrm{C}$ and $0.25 \mathrm{ng} \mathrm{l}^{-1}$ at $37^{\circ} \mathrm{C}$. In medium AI (only $0.25 \%$ glycerol) plus sodium acetate trihydrate $\left(500 \mathrm{mg} \mathrm{l}^{-1}\right)$, biotin synthesis was $6.6 \mathrm{ng} \mathrm{l}^{-1}$ at $30^{\circ} \mathrm{C}^{\circ}$ and $0.3 \mathrm{ng} \mathrm{l}^{-1}$ at $37^{\circ} \mathrm{C}$. Thus, the effects of these supplements were probably made by supplying products of biotin-dependent enzyme systems.

\section{Sporulation of biotin-sufficient and biotin-deficient organisms}

In medium AI plus I mM-CaCl ${ }_{2}$ with glycerol ( $\mathrm{I} \%$ or $0.2 \%$ ) as carbon source, B. megaterium NCIB758I did not sporulate at 30 or $37^{\circ} \mathrm{C}$ whether or not biotin was present. The organisms were made to sporulate by limiting glucose in medium $\mathrm{A} 2$ to $0.2 \%$ and adding I $\mathrm{mM}-\mathrm{CaCl}_{2}$. The number of spores per $\mathrm{ml}$ in a culture grown at $37^{\circ} \mathrm{C}$ without biotin was only about 0.05 of that in a culture grown at $37^{\circ} \mathrm{C}$ with biotin (Table 2). Furthermore, if L-aspartate was added instead of biotin, the same number of spores was formed per $\mathrm{ml}$ at $37^{\circ} \mathrm{C}$. Addition of dipicolinate also markedly increased the yield of spores at $37^{\circ} \mathrm{C}$ in the absence of biotin. Cultures grown at $30^{\circ} \mathrm{C}$ formed approximately the same number of spores per $\mathrm{ml}$ culture whether or not biotin was present, and this yield was always higher than at $37^{\circ} \mathrm{C}$.

\section{Electron microscopy}

Organisms grown at $37^{\circ} \mathrm{C}$ in the presence of biotin had the appearance of normal B. megaterium by electron microscopy. Organisms grown at $37^{\circ} \mathrm{C}$ without biotin were 

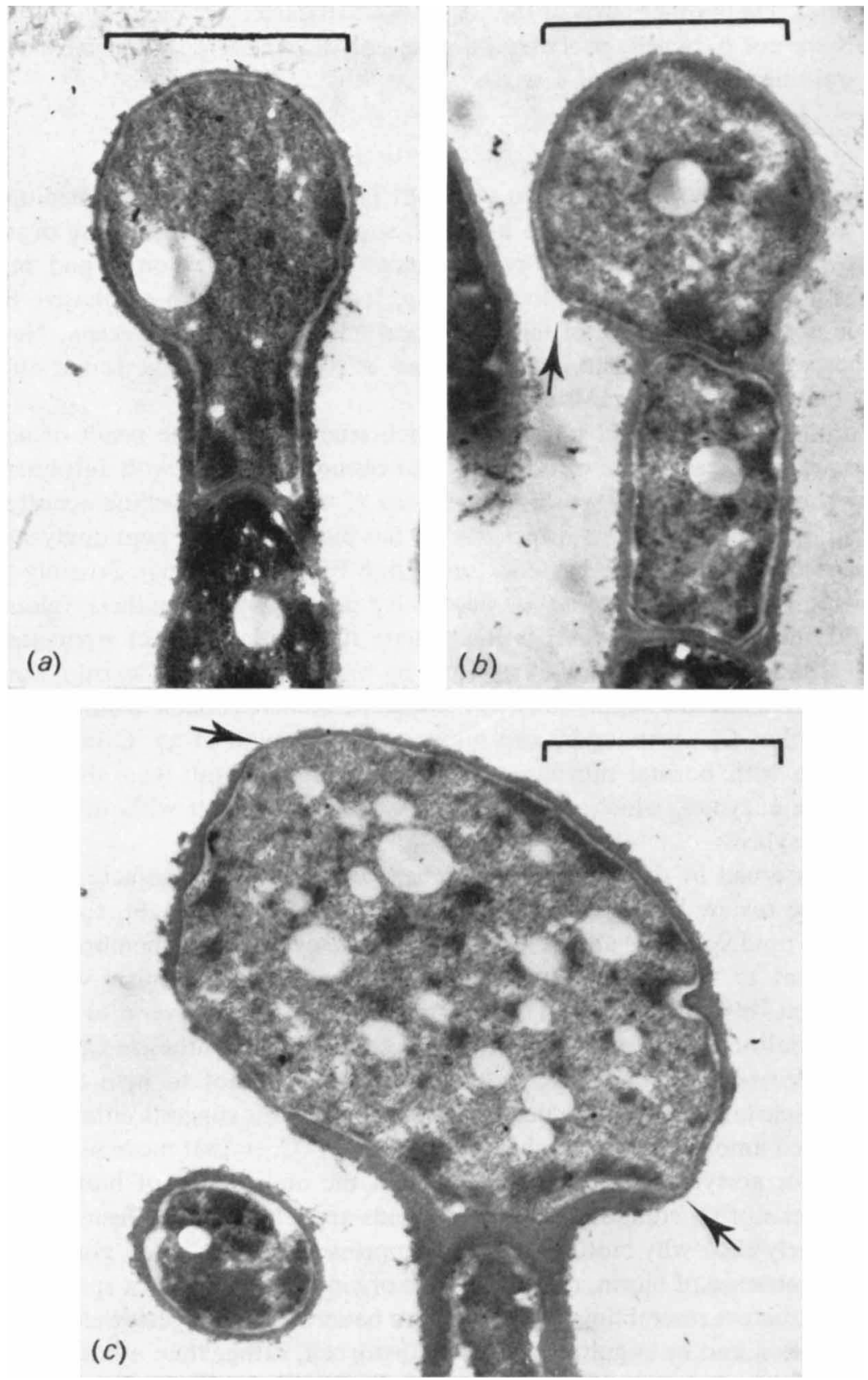

Fig. 3. Deformed B. megaterium NCIB758I grown on medium AI at $37^{\circ} \mathrm{C}$ without biotin. (a) Terminal swelling; (b) terminal swelling and thinning of wall (at arrow); (c) gross swelling and thinning of wall (at arrows). Bar markers represent $\mathrm{I} \mu \mathrm{m}$. 
frequently swollen at the ends (Fig. 3). The wall was thinner round the swelling though of normal thickness in other parts of the organism. Satisfactory photographs of filamentous organisms were not obtained, probably because only a relatively short length of a twisted filament would lie in the plane of a section.

\section{DISCUSSION}

Synthesis of biotin by $B$. megaterium NC1B758I in a chemically defined medium at $37^{\circ} \mathrm{C}$ is limited, so that there is insufficient biotin to supply all the needs of the organisms for normal growth. The most obvious consequences are altered colonial and microscopic appearances, and a limited ability to sporulate. It is important to emphasize that biotin deficiency is not the only cause of morphological change in B. megaterium. Nevertheless, several other workers (e.g. Chan, 1964; Ahmad \& Rose, 1962) have found altered morphology in biotin-deficient organisms.

The deformities caused at $37^{\circ} \mathrm{C}$ by biotin deficiency may be the result of altered wall synthesis, or of a decreased rate of synthesis that cannot keep pace with autolysis. Electron microscopy showed apparently weak, thin regions of wall where swelling occurred. Biotin, however, is not known to play a direct role in the biosynthesis of peptidoglycan or other wall polymers of Gram-positive bacteria (see review by Osborn, 1969). Possibly the supply (from aspartate) of amino acids that are needed for peptidoglycan synthesis (glutamate and diaminopimelate in B. megaterium) is inadequate if carboxylation of pyruvate (to form oxaloacetate, and hence aspartate) is restricted by biotin deficiency (Cazzulo, Sundaram \& Kornberg, 1969). That this supply may be inadequate seems probable from the finding that aspartate (or other $\mathrm{C}_{4}$ compounds) can allow normal growth at $37^{\circ} \mathrm{C}$ in the absence of biotin. Growth with normal morphology on acetate might result from the production of glyoxylate cycle enzymes, which allow $\mathbf{C}_{\mathbf{4}}$ compounds to be made without participation of pyruvate carboxylase.

Biotin is concerned in the synthesis of higher fatty acids, as a cofactor of acetyl-CoA carboxylase (see review by Vagelos, 1964). Deficiency of biotin might, therefore, lead to disturbances in lipid synthesis and hence to a defective cytoplasmic membrane. Damage to the membrane at $37^{\circ} \mathrm{C}$ cannot be very drastic, otherwise the organism would not grow without biotin at this temperature. The membrane is the site of several of the enzymes of wall synthesis (Salton, 1974), and a defective membrane might synthesize an abnormal wall. Nevertheless, provision of aspartate in the medium ought not to help directly in lipid synthesis, yet aspartate does restore normal morphology. This suggests either that aspartate spares the limited amount of biotin which is made at $37^{\circ} \mathrm{C}$, so that more biotin is available as a cofactor for acetyl-CoA carboxylase, or that the main result of biotin deficiency is impaired synthesis of $\mathrm{C}_{4}$ compounds, and the lipids are relatively unaffected.

It is not entirely clear why biotin deficiency suppresses sporulation on glucose limitation. At $37^{\circ} \mathrm{C}$ in the absence of biotin, only about one organism in 20 forms a spore, and in most organisms no structure resembling a forespore can be seen. This suggests that formation of a sporulation septum and/or engulfment may be disturbed, rather than a later stage, such as cortex formation or synthesis of dipicolinate. On the other hand, aspartate allowed sporulation in the absence of biotin, as did dipicolinic acid to a lesser extent. Consequently, it seems possible that aspartate stimulates sporulation partly by acting as a precursor of dipicolinic acid.

We are grateful to several members of the Department of Human Biology and Anatomy, University of Sheffield, who carried out the electron microscopy, and to Dr A. Salem for 
much help and advice. R.M.A. received financial support from Riyad University, Saudi Arabia.

\section{REFERENCES}

AHMAD, F. \& RoSE, A. H. (1962). Effect of biotin-sparing substances on growth of biotin-deficient Saccharomyces cerevisiae and on the synthesis of nucleic acids and protein. Journal of General Microbiology 28, $147-160$.

AL-ssum, R. M. \& WhIT, P. J. (1974). Biotin deficiency in Bacillus megaterium. Proceedings of the Society for General Microbiology 1, 69-70.

CAZZuLo, J. J., Sundaram, T. K. \& Kornberg, H. L. (1969). Regulation of pyruvate carboxylase formation from the apo-enzyme and biotin in a thermophilic bacillus. Nature, London 223, I137-I I38.

ChAN, E. C. S. (1964). Morphological aberration of Arthrobacter globiformis cells due to biotin deficiency. Journal of Bacteriology 87, 641-65I.

Echlin, P. (1964). Intra-cytoplasmic membraneous inclusions in the blue-green alga, Anacystis nidulans. Archiv für Mikrobiologie 49, 267-274.

EISENBERG, M. A. (1973). Biotin: biogenesis, transport, and their regulation. Advances in Enzymology 38, $317-372$.

OsBorn, M. J. (1969). Structure and biosynthesis of the bacterial cell wall. Annual Review of Biochemistry 38, $501-538$.

PaI, C. H. \& Lichstern, H. C. (1962). Control of biotin synthesis in Escherichia coli by exogenous biotin. Biochimica et biophysica acta 65, $159-160$.

Salton, M. R. J. (1974). Membrane associated enzymes in bacteria. Advances in Microbial Physiology II 213-283.

VAGELOS, P. R. (1964). Lipid metabolism. Annual Review of Biochemistry 33, 139-172.

WHITE, P. J. (1972). The nutrition of Bacillus megaterium and Bacillus cereus. Journal of General Microbiology 71, 505-514. 